\title{
A simultaneous TG-DTG-DSC-quadrupole mass spectrometric study
}

\author{
Thermal decomposition of benzyl-triethyl-ammonium tetrafluoroborate
}

\author{
M. R. R. Prasad • K. Sudhakarbabu • \\ B. Sreedhar $\cdot$ D. Keerthi Devi
}

Received: 22 August 2013/Accepted: 19 November 2013/Published online: 18 January 2014

(C) The Author(s) 2014. This article is published with open access at Springerlink.com

\begin{abstract}
Mechanistic aspects of the thermal decomposition of benzyl-triethyl-ammonium tetrafluoroborate (BTEATFB) employing simultaneous TG-DSC coupled with a quadrupole mass spectrometer are considered in this work. The experiments were conducted in an inert atmosphere of helium. The decomposition of BTEATFB proceeds through several competing mechanisms. While nucleophilic substitution reaction occurs through the formation of a tertiary amine and plays an important role in the initial stages of the decomposition, and the probability of Hoffman elimination also exists.
\end{abstract}

Keywords Benzyl-triethyl A Ammonium ·

Tetrafluoroborate $\cdot$ Decomposition $\cdot$ Hoffman

elimination $\cdot$ Nucleophilic substitution

\footnotetext{
M. R. R. Prasad ( $₫) \cdot$ K. Sudhakarbabu

Department of Chemistry, Sri Krishnadevaraya University,

Anantapur 515055, India

e-mail: mandapaka.p@gmail.com

K. Sudhakarbabu

e-mail: drksbabu9@gmail.com

Present Address:

M. R. R. Prasad

Flat-201, Plot Nos. 31 \& 32, Indraprastha Apartments, Indira Nagar Colony, Venkatapuram, Lothkunta, Alwal, Secunderabad 500015, India

\section{B. Sreedhar · D. K. Devi}

Inorganic \& Physical Chemistry Division, Indian Institute of Chemical Technology (IICT), Tarnaka, Hyderabad 500007, India

e-mail: sreedharb@iict.res.in
}

\section{Introduction}

Among many other quaternary ammonium compounds: halides, hydroxides, and tetrafluoroborates of benzyl-triethyl- ammonium and benzyl-tri- $n$-butyl ammonium cations have been extensively used as phase-transfer catalysts [1-7]. Quaternary ammonium compounds such as choline are important in medical research [8]. Inclusion in the synthesis mixture of various quaternary salts, particularly bulky alkyl ammonium cations, has introduced a new structure-directing parameter into the synthesis mechanism [9], so that new type of zeolites have been patented [10-12] to widen up the scope of zeolite chemistry and applications. Toxicological evaluation was performed on human colon carcinoma cell line (CaCo-2) of ionic liquids based on imidazolium, guanidinium, ammonium, phosphonium, pyridinium, and pyrrolidinium cations [13].

The present work envisages studying the thermal decomposition of benzyl-tri-ethyl ammonium tetrafluoroborate (BTEATFB) in an inert atmosphere of Helium, and has not been considered hitherto. This is a prelude to using this compound as an additive for the modification of the thermal decomposition of ammonium per chlorate, a widely used oxidizer in composite solid rocket propellant technology even today.

\section{Experimental}

The pure compound BTEATFB was procured from M/s. Aldrich Chemicals. The thermal decomposition was studied using simultaneous TG-DSC coupled with Quadrupole Mass Spectrometer (QMS). Measurements were carried out at Netzsch's laboratory, Germany, employing STA/QMS 409-403 systems. 


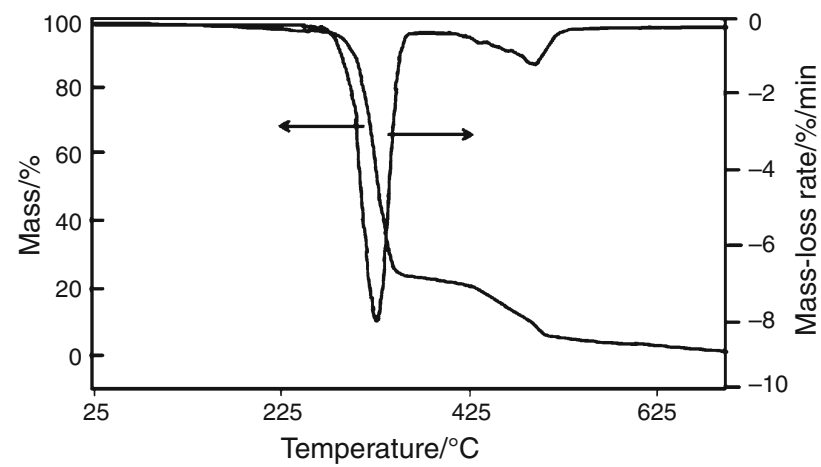

Fig. 1 TG curve of benzyl-triethyl-ammonium tetrafluoroborate. The derivative curve (mass-loss rate) is also plotted

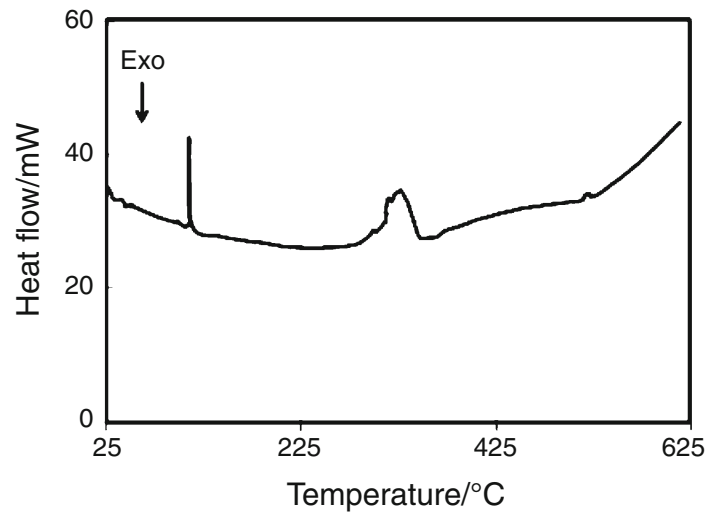

Fig. 2 DSC curve of benzyl-triethyl-ammonium tetrafluoroborate

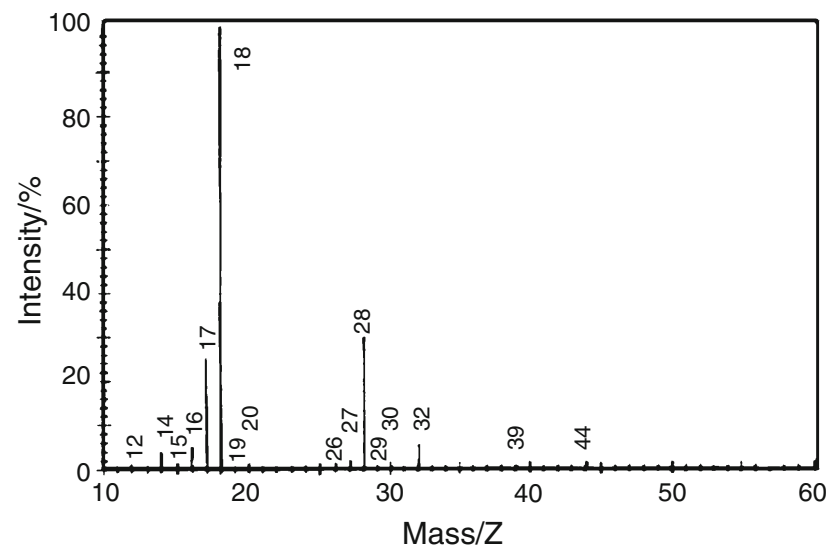

Fig. 3 Mass spectrum of evolved gases at a sample temperature of $324{ }^{\circ} \mathrm{C}$

A sample heating rate of $5{ }^{\circ} \mathrm{C} \mathrm{min}^{-1}$, an inert atmosphere of Helium, and a gas flow rate of $75 \mathrm{~mL} \mathrm{~min}^{-1}$ were employed in this study. The QMS data acquisition was carried out in the scan mode, in the mass range of 10-200 amu.

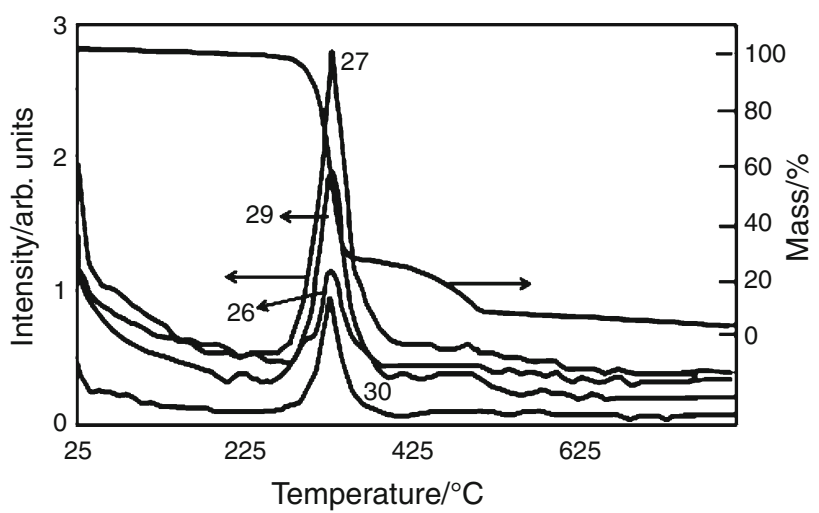

Fig. 4 Intensity of mass fragments with $\mathrm{m} / \mathrm{z}=26,27,29$, and 30 of evolved gases as a function of temperature

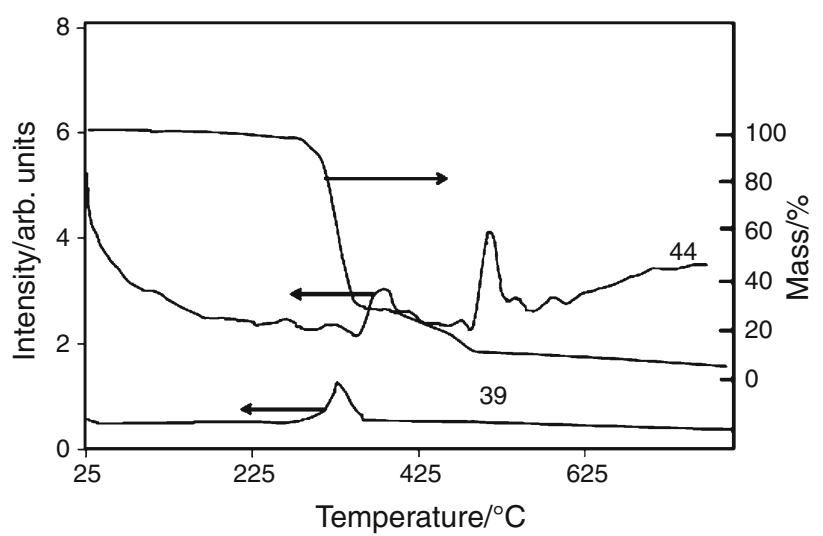

Fig. 5 Intensity of mass fragments with $\mathrm{m} / \mathrm{z}=39$ and 44 of evolved gases as a function of temperature

Table 1 Assignment for the evolved mass fragments during thermal decomposition of benzyl-triethyl-ammonium tetrafluoroborate

\begin{tabular}{ll}
\hline$m / z$ value & Peak assignment \\
\hline 14 & $\mathrm{~N}^{+}$ \\
17 & $\mathrm{NH}_{3}$ \\
18 & $\mathrm{H}_{2} \mathrm{O}$ \\
26 & $\mathrm{CH} \equiv \mathrm{CH}$ \\
28 & $\mathrm{CH}_{2}=\mathrm{CH}_{2}$ \\
30 & $\mathrm{CH}_{2}=\mathrm{NH}_{2}$ \\
39 & $\mathrm{C}_{2} \mathrm{HN}$ \\
44 & $\mathrm{CH}_{3} \mathrm{CH}_{2} \mathrm{~N}^{+} \mathrm{H}$ \\
58 & $\mathrm{CH}_{2}=\mathrm{NH}^{+} \mathrm{C}_{2} \mathrm{H}_{5}$ \\
65 & $\left(\mathrm{C}_{7} \mathrm{H}_{7}\right)$ tropylium \\
\hline
\end{tabular}

\section{Results and discussion}

The TG-DTG curves of BTEATFB are shown in Fig. 1. This compound decomposes in two distinct steps with a mass loss of 78.5 and $20.3 \%$ (as observed from TG). 


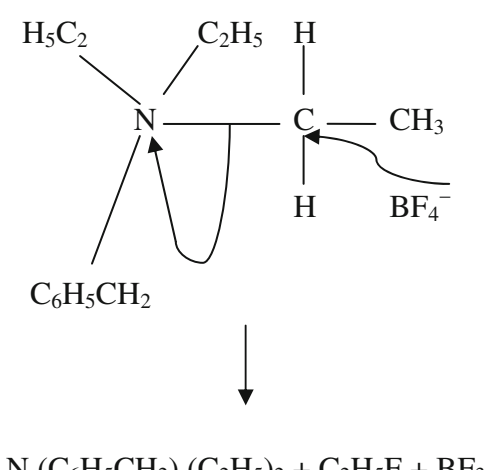

$\mathrm{N}\left(\mathrm{C}_{6} \mathrm{H}_{5} \mathrm{CH}_{2}\right)\left(\mathrm{C}_{2} \mathrm{H}_{5}\right)_{2}+\mathrm{C}_{2} \mathrm{H}_{5} \mathrm{~F}+\mathrm{BF}_{3}$

(Alternately)

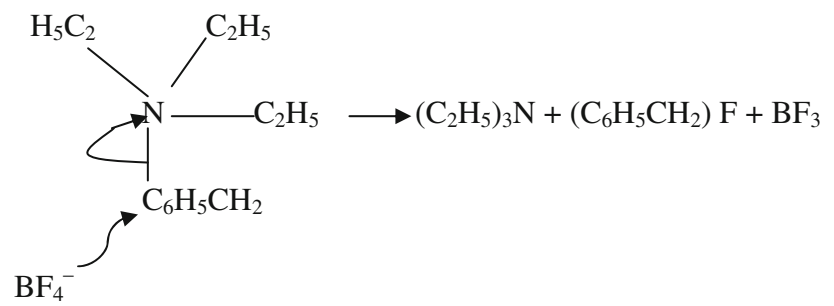

Scheme 1 Decomposition pathways of benzyl-triethyl-ammonium tetrafluoroborate

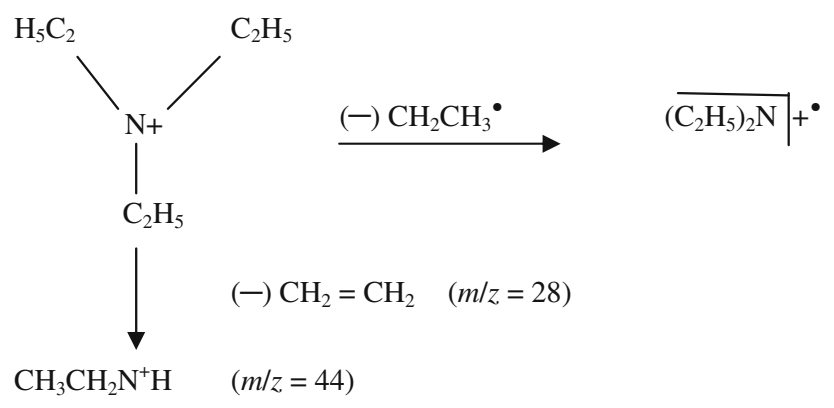

Scheme 2 Degradation pathway of triethylamine

Maximum mass-loss rates were observed at 325 and $489{ }^{\circ} \mathrm{C}$.

Figure 2 shows the DSC curve of BTEATFB. The enthalpy of fusion was found to be $172 \mathrm{~J} \mathrm{~g}^{-1}$ (DSC). A second endothermic (broad double peak) was observed between 280 and $350{ }^{\circ} \mathrm{C}$ (with peak temperature at $325^{\circ} \mathrm{C}$ ). This peak is caused by the decomposition of the compound BTEATFB. The endothermic decomposition enthalpy is $1,222 \mathrm{~J} \mathrm{~g}^{-1}$. In the DSC curve, endothermic peaks occur at 109.4 and $325{ }^{\circ} \mathrm{C}$, corresponding to fusion and decomposition processes of the compound BTEATFB.

Figure 3 shows the intensities of mass fragments formed in the quadrupole mass spectrometer as the sample undergoes thermal decomposition at $324{ }^{\circ} \mathrm{C}$. Significant intensities were observed of mass fragments with $\mathrm{m} / \mathrm{z}=$ $14,16,17,18,28$, and 32 . These peaks are due to the formation of $\mathrm{H}_{2} \mathrm{O}, \mathrm{N}_{2}, \mathrm{O}_{2}$ and $\mathrm{C}_{2} \mathrm{H}_{6}$ as decomposition products.

The intensities of mass fragments with $m / z=26,27,29$, and 30 as a function of sample temperature are shown in Fig. 4 along with TG-curve; those corresponding to $m / z=39$ and 44 are shown in Fig. 5, and those corresponding to $m / z=58,63$, and 65 are shown in Fig. 6. The significant intense peaks and their assignment are shown in Table 1.

The thermal decomposition of complex fluoro anions at temperatures of interest is characterized by the formation of gaseous components such as $\mathrm{BF}_{3}, \mathrm{NH}_{3}$, and $\mathrm{HF}$ [14]. For example, the decomposition of $\mathrm{NH}_{4} \mathrm{BF}_{4}$ is represented by the reaction

$\mathrm{NH}_{4} \mathrm{BF}_{4} \rightarrow \mathrm{NH}_{3}(\mathrm{~g})+\mathrm{HF}(\mathrm{g})+\mathrm{BF}_{3}(\mathrm{~g})$

It is well-accepted that the quaternary ammonium compounds of the type $\mathrm{R}_{4} \mathrm{~N}^{+} \mathrm{X}^{-}$decompose thermally to yield an amine $\left(\mathrm{R}_{3} \mathrm{~N}\right)$ and the corresponding alkyl compound [15].

$\mathrm{NR}_{4} \mathrm{BX}_{4} \rightarrow \mathrm{NR}_{3}(\mathrm{~g})+\mathrm{RX}(\mathrm{g})+\mathrm{BX}_{3}(\mathrm{~g})$

As BTEATFB is analogous to tetra alkyl ammonium compounds, its thermal decomposition can be predicted to follow similar pattern as for $\mathrm{NH}_{4} \mathrm{BF}_{4}$.or for $\mathrm{NR}_{4} \mathrm{BX}_{4}$.

The thermal decomposition of benzyl quaternaryammonium compounds proceeds through several competing reaction mechanisms. The products formed depend on the temperature of pyrolysis and the bulkiness of the alkyl substituent about the quaternary ammonium center. The major components are mainly those from a simple nucleophilic substitution reaction between the fluoroborate anion and the bulky quaternary ammonium cation. The reaction path and the possible products are shown in Scheme 1.

The formation of an intermediate amine in the thermal decomposition of quaternary ammonium compounds was reported by Haskins and Mitchell [8], Udupa [16], Nambiar et al. [17], and Prasad and Krishnamurthy [18]. Similar observations were made in the thermal decomposition of tetra alkyl ammonium thiomolybdates [19] and thiotungastates [20].

Due to the bulkiness of the benzyl group, the possibility of formation of its corresponding amine is doubtful. The triethyl amine formed according to Scheme 1 boils at $88.8{ }^{\circ} \mathrm{C}$, and hence under experimental conditions (at higher temperatures), being unstable, undergoes further fragmentation according to Scheme 2.

Further, the $\mathrm{C}-\mathrm{C}$ bond next to the heteroatom (nitrogen) is frequently cleaved, leaving the charge on the fragment containing the heteroatom (nitrogen) whose non-bonding electrons provide resonance stabilization. Accordingly, the triethyl amine formed as per Scheme 1 can yield 
Scheme 3 Cleavage at $\mathrm{C}-\mathrm{C}$ bond next to heteroatom

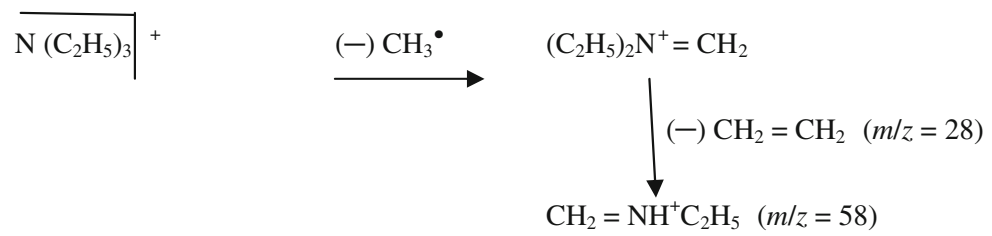

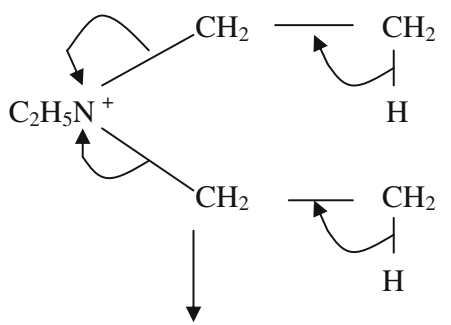

$\mathrm{CH}_{3} \mathrm{CH}_{2} \mathrm{NH}_{2} \quad+\quad 2\left[\mathrm{CH}_{2}=\mathrm{CH}_{2}\right]$

$(m / z=45) \quad(m / z=28)$

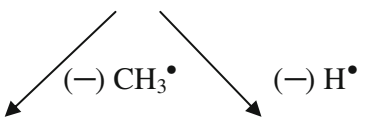

$\mathrm{CH}_{2}=\mathrm{NH}_{2} \quad \mathrm{CH}_{3} \mathrm{CH}=\mathrm{N}^{+} \mathrm{H}_{2} \quad(m / z=44)$

$(m / z=30)$

Scheme 4 Alternate path for triethyl amine decomposition

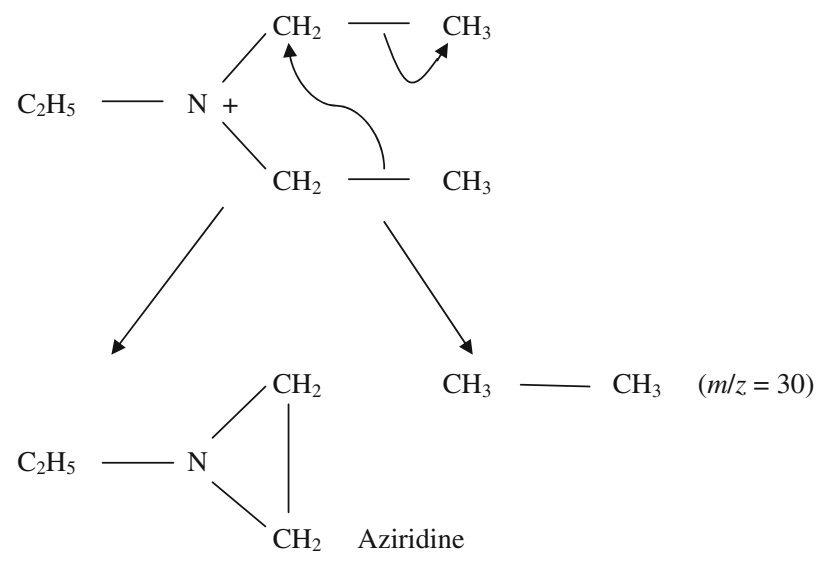

Scheme 5 Stable cyclic aziridine formation
Alternately, the ionized triethyl amine, with the elimination of two molecules of ethylene (Scheme 4) can yield ethylamine which boils at $16.6^{\circ} \mathrm{C}$ can further yield fragments $\mathrm{CH}_{2}=\mathrm{NH}_{2}(\mathrm{~m} / \mathrm{z}=30)$ and $\mathrm{CH}_{3} \mathrm{CH}=\mathrm{N}^{+} \mathrm{H}_{2}(\mathrm{~m} / \mathrm{z}=44)$.

A peak corresponding to $\mathrm{m} / \mathrm{z}=30$ is good though not conclusive evidence for a straight chain primary amine.

Yet another possibility for intermediary amine so formed according to Scheme 1 to undergo cyclization [18] as per Scheme 5 which explains for the appearance of molecular fragment corresponding to $\mathrm{m} / \mathrm{z}=30$.

The most studied reaction of quaternary ammonium salts is the Hofmann degradation [21] which would give rise to benzyldimethylamine, hydrogen fluoride, and the corresponding alkene (Scheme 2). The evidence for the Hofmann elimination depends on the detection of the alkene. The appearance of the mass fragment corresponding to $m / z=28$ is the evidence to conclude that the Hofmann elimination is taking place (Fig. 2). Further, in alkyl

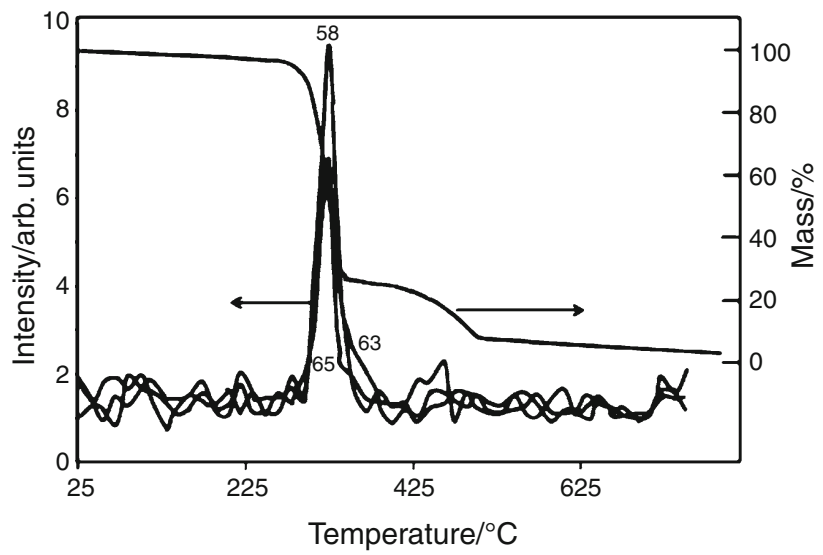

Fig. 6 Intensity of mass fragments with $\mathrm{m} / \mathrm{z}=58,63$, and 65 of evolved gases as a function of temperature
Scheme 6 Formation of Tropylium ion

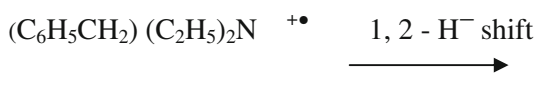


substituted aromatic compounds, cleavage is possible at the bond $\beta$ to the ring, giving the resonance stabilized benzyl ion, or more likely, the tropylium ion [22]. These are again relatively high temperature processes taking place.

The appearance of a peak corresponding to $\mathrm{m} / \mathrm{z}=26$ and 65 (Fig. 6) supports the above hypothesis.

\section{Conclusions}

In the thermal decomposition of BTEATFB, while at low temperatures simple displacement reactions appear to be predominant. At higher temperatures, more complex multicenter reactions are the probability. Observation of a strong peak corresponding to $\mathrm{m} / \mathrm{z}=28$ is confirmative of the existence of Hofmann elimination process.

Acknowledgements Dr. M. R. R. Prasad would like to profusely thank and acknowledge the experimental support extended by $\mathrm{M} / \mathrm{s}$. Netzsch Instruments, Germany in the present research work.

Open Access This article is distributed under the terms of the Creative Commons Attribution License which permits any use, distribution, and reproduction in any medium, provided the original author(s) and the source are credited.

\section{References}

1. Dockx J. Quaternary ammonium compounds in organic synthesis. Synthesis. 1973;8:441-56.

2. Makosza M, Fedorynski M. Catalysis in two-phase systems. Phase transfer related phenomena. Adv Catal. 1987;35:375.

3. Goldberg Y. Selected problems of phase-transfer catalysis. New York: Gordon and Breach; 1992.

4. Dehmlow EV, Dehmlow SS. Phase-transfer catalysis. 3rd ed. New York: VCH; 1993.

5. Starks CM, Liotta CL, Halpern M. Phaste-transfer catalysis: fundamentals. Applications and industrial perspectives. New York: Chapman and Hall; 1994.

6. Halpen ME. Phase-transfer catalysis: mechanisms and syntheses. Washington, DC: ACS; 1997.
7. Sasson Y, Newmann R, editors. Handbook of phase-transfer catalysts. London: Blackie; 1997.

8. Haskins NJ, Mitchell R. Thermal degradation of some benzyltrialkylammonium salts using pyrolysis-gas chromatographymass spectrometry. Analyst. 1991;116:901-3.

9. Flanigen EM. Molecular sieve zeolite technology-the first twenty five years. In: Rees LV, editor. Proceedings of the 5th International Conference on Zeolites. London: Heyden; 1980. p. 760-780.

10. Acara NA, Kenmore NY. Zeolite N and process for preparing same. 1968; US Patent 3,414,602.

11. Plank CJ, Rosinski EJ, Rubin MK. Crystalline zeolite and method of preparing same. 1977; US Patent 4,046,859.

12. Rubin MK, Rosinski EJ, Plank CJ. Crystalline zeolite ZSM-34 and method of preparing the same. 1978; US Patent 4,086,186.

13. Frade RFM, Rosatella AA, Marques CS, Branco LC, Kulkarni PS, Mateus NM, Afonso CAM, Duarte CMM. Toxicological evaluation on human colon carcinoma cell line $(\mathrm{CaCo}-2)$ of ionic liquids based on imidazolium, guanidinium, ammonium, phosphonium, pyridinium and pyrrolidinium cations. Green Chem. 2009;11:1660-1665.

14. Mayer SW, Weinberg EK, Schieler L. Procedures for suppressing premature exothermic decomposition in ammonium per chlorate. AIAA J. 1970;8(7):1328-34.

15. Hofmann AW. Hofmann elimination. Ann Chem Pharm. 1851; 78:253.

16. Udupa MR. Thermal decomposition of tetraethyl ammonium per chlorate. Propellants Explos Pyrotech. 1982;7:155-7.

17. Nambiar PR, Pai Verneker SR, Jain SR. Explosive sensitivity of methyl ammonium per chlorates. J Therm Anal Calorim. 1975;8:15-26.

18. Prasad MRR, Krishnamurthy VN. Thermal decomposition and pyrolysis-GC studies on tetra alkyl-substituted ammonium hexafluorophosphates. Thermochim Acta. 1991;185:1-10.

19. Poisot M, Bensch W, Fuentes S, Alonso G. Decomposition of tetra-alkylammonium thiomolybdates characterized by thermoanalysis and mass spectrometry. Thermochim Acta. 2006;444: $35-45$.

20. Poisot M, Bensch W. Decomposition of tetraalkylammonium thiotungstates characterized by thermoanalysis, mass spectrometry, X-ray diffractometry and scanning electron microscopy. Thermochim Acta. 2007;453:42-51.

21. Ollis WD, Rey H, Sutherland IO. Base catalyzed rearrangements involving ylide intermediates. Part 15. The mechanism of the Stevens [1, 2] rearrangement. J Chem Soc Perkin Trans. 1983;1:1009-27.

22. Silverstein RM, Webster FX. Spectrometric identification of organic compounds. 6th ed. Delhi: Nice Printing Press; 2006. p. 14. 